\title{
STUDI PRODUK HALAL DAGING AYAM POTONG DENGAN PENDEKATAN RANTAI PASOK (SUPPLY CHAIN) DI MAKASSAR
}

\author{
Aslan Risyaldi ${ }^{1}$, Muhammad Nusran ${ }^{2}$, Dirgahayu Lantara ${ }^{3}$ \\ 1,2.3 Jurusan Teknik Industri, Universitas Muslim Indonesia, Makassar, Indonesia \\ Korespondensi Author: e-mail: muhammad.nusran@umi.ac.id
}

\begin{abstract}
Supply Chain is a concept and regulatory system related to product flow, information flow and financial flows. Activities in the supply chain for broilers consist of the process of raising chicken products by breeders, then processing them into chicken meat that is ready to be marketed from breeders to consumers. The purpose of this study was to analyze the supply chain for chicken meat products and to determine the availability of chickens in the Chicken Slaughterhouse and the availability of chickens in the city of Makassar. Data collection methods are carried out by observation and interviews. Data processing with the preparation of problems in a hierarchy, Validity and Reliability Examiners, Supply chain mapping and hierarchical determination, Calculation of the actual value of each matrix, Inserting weights into the decision matrix, Calculating the normalization value. Data analysis that has been collected is then processed using the Supply Chain Operations Reference (SCOR) method. Of the 15 sub-districts in Makassar city, there are 4 sub-districts which are slaughter centers namely Tamalate (97,643), Manggala (100,762), Biringkanaya (999,554) and Tamalanrea (88,895). where 3 districts are directly adjacent to the buffer area for chicken products, namely Maros and Gowa. The potential supply of chickens to Makassar city will be even greater along with the demand for chicken meat protein. The conclusion is the supply chain channel for chicken products with 3 alternatives, starting from livestock producers, collecting traders, retailers, consumers, then the second alternative is starting from producers, collecting traders and consumers. And the third alternative is starting from the cage, basket, slaughterhouse and consumers.
\end{abstract}

Keywords: Halal Supply Chain, Chicken Meat, Chicken Slaughterhouse

Abstrak: Rantai pasok (Supply Chain) merupakan suatu konsep dan sistem pengaturan yang berkaitan dengan aliran produk, aliran informasi maupun aliran keuangan. Kegiatan dalam rantai pasok ayam pedaging terdiri atas proses pemeliharaan produk ayam oleh peternak, kemudiaan diolah menjadi daging ayam yang siap untuk dipasarkan dari perternak hingga hingga kekonsumen. Tujuan dalam penelitian ini adalah untuk menganalisis alur rantai pasok (supply chain) pada produk daging ayam dan untuk mengetahui ketersediaan ayam di Rumah Potong Ayam serta ketersediaan ayam di kota Makassar. Metode pengumpulan data yang dilakukan dengan observasi dan wawancara.Pengolahan data dengan Penyusunan masalah dalam suatu hirarki, Penguji Validitas dan Realibilitan, Pemetaan rantai pasok dan penentuan hierarki, Perhitungan nilai aktual dari masing - masing matriks, Memasukkan bobot ke dalam matriks keputusan, Perhitungan nilai normalisasi. Analisis Data yang telah di kumpulkan kemudian diolah dengan metode Supply Chain Operations Reference (SCOR). Dari 15 kecamatan di kota Makassar, ada 4 kecamatan yang merupakan sentra penyembelihan yakni Tamalate (97.643), Manggala (100,762), Biringkanaya (999.554) dan Tamalanrea (88.895). dimana 3 kecamatan berbatasan langsung dengan daerah penyanggah 
Produk ayam potong yakni Maros dan Gowa. Potensi pasokan ayam ke kota Makassar, akan semakin besar seiring dengan jumlah kebutuhan protein daging ayam. Kesimpulan adalah saluran rantai pasok produk ayam potong dengan 3 alternatif yakni dimulai dari Produsen perternak, Pedagang pengumpul, Pedagang pengecer, konsumen, kemudian alternatif ke-2 adalah dimulai dari produsen, Pedagang pengumpul dan konsumen. Dan alternatif ke-3 adalah mulai dari kandang, bakul, Rumah Potong Ayam dan Konsumen

Kata kunci : Halal Supply Chain, Daging Ayam Potong, Rumah Potong Ayam

\section{PENDAHULUAN}

Daging ayam merupakan jenis daging yang banyak dikonsumsi oleh masyarakat karena daging ayam mengandung kadar protein tinggi yang dibutuhkan oleh tubuh, mempunyai cita rasa yang baik sehinga dapat diterima semua golongan masyarakat dan semua umur, cukup mudah diolah menjadi produk olahan yang bernilai tinggi serta mudah untuk dikomsumsi (Drayanto, 2009)

Ayam potong adalah merupakan ayam hasil budidaya teknologi yang memiliki krakteristik ekonomis dan ciri khas yaitu pertumbuhan yang cepat, komversi pakan yang baik dan dapat dipotong pada usia yang relatif mudah sehingga sirkulasi pemeliharaanya lebih cepat dan efisien serta menghasilkan daging yang berkualitas baik. (Arina Budiarti, 2012).

Pada suatu supply chain ada 3 macam aliran yang harus dikelolah. Pertama adalah aliran barang yang mengalir dari hulu (upstream) ke hilir (downsteream). Kedua adalah aliran uang dan sejenisnya yang mengalir dari hilir ke hulu. Ketiga adalah aliran informasi yang bisa terjadi dari hulu ke hilir ataupun sebaliknya. Infomasi tentang persedian produk yang masih ada di masing-masing devisi sering dibutuhkan oleh distributor maupun oleh instansi. Infomasi tentang ketersediaan kapasitas produksi yang dimiliki oleh supplier juga sering dibutuhkan oleh instansi. Infomasi tentang status pengiriman bahan baku sering dibutuhkan oleh instamsi yang mengirim maupun yang menerima. Instansi pengapalan harus membagi infomasi seperti ini supaya pihak-pihak berkepentingan bisa memonitor untuk kepentingan perencanaan yang lebih akurat.

Supply chain adalah jaringan instansi - instansi yang secara bersama- sama berkerja untuk menciptakan dan menghantarkan suatu produk ke tangan pemakai akhir (end user). Instansi-instansi tersebut biasanya termasuk supplier, instansi, distributor, took atau ritel, serta instansi-instansi pendukung seperti instansi jasa logistic (punjawan, 2005).

Adapun Prinsip dalam supply chain Managemen adalah sebagai berikut (Siahaya, 2013).

1. Prinsip integrasi, semua elemen yang terlibat dalam rangkaian supply chain management (SCM) berada dalam satu kesatuan yang kompak dan bersama menyadari adanya saling ketergantungan.

2. Prinsip jejaring, semua elemen berada dalam hubungan kerja yang selaras.Prinsip ujung ke ujung, proses operasional mencakup elemen pemasok yang paling hulu sampai ke 
komsumen yang paling hilir.

3. Prinsip saling tergantung, setiap elemen dalam supply chain management (SCM) menyadari bahwa untuk mencapai tujuan bersama dan meningkatkan daya asing, diperlukan kerjasama yang paling menguntungkan.

4. Prinsip komunikasi, data yang akurat memberikan infomasi tepat untuk memperlancarkan alirang barang.

5. Prinsip kemitraan, pemasok, manufaktur,distributor dan pelanggan berkerja sama saling membagi dan mengkomunikasihkan informasi, mempunyai tujuan yang sama, saling percaya dan mengutamakan kualitas dan waktu.

6. Prinsip dukungan, mendapat dukungan penuh dari manajemen dan fungsi operational perusahaan dalam proses perencanaan, koordinasi, pelaksanaan dan pengendalian.

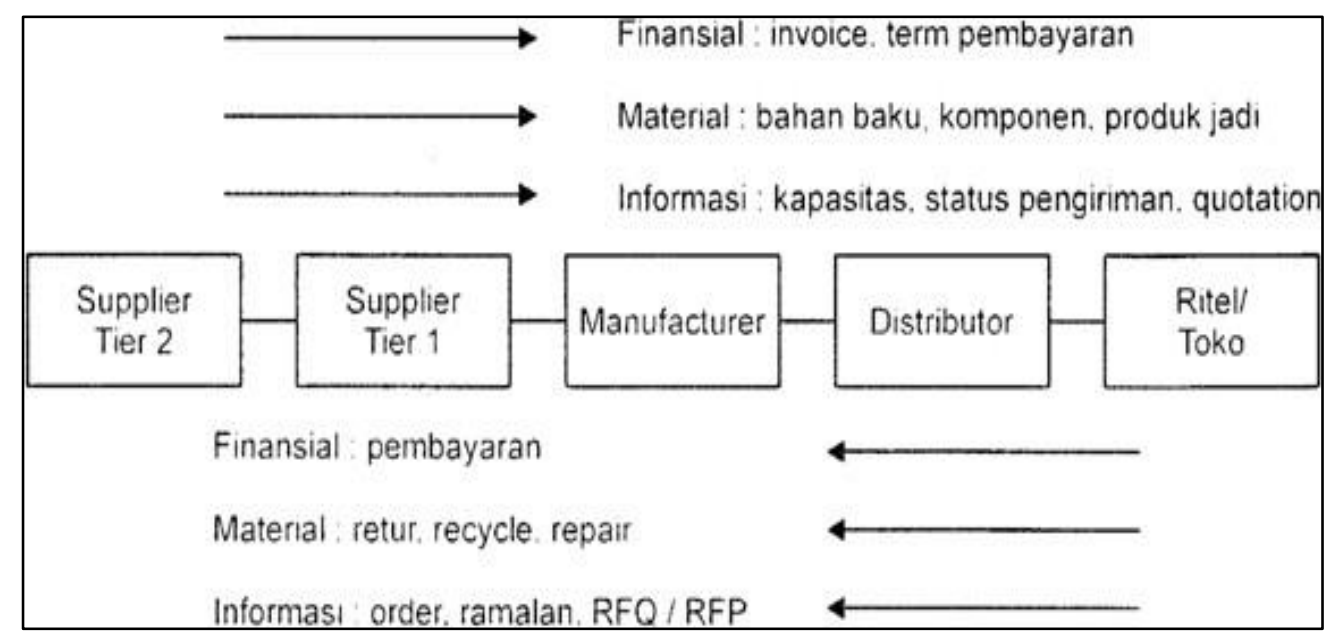

Gambar 1 : Simplifikasi Model Supply Chain (Sumber : Pujawan 2005)

\section{METODE}

\section{Gambaran umum lokasi penelitian}

Makassar adalah Ibu Kota Provinsi Sulawesi Selatan, yang terletak di bagian Selatan Pulau Sulawesi yang dahulu disebut Ujung Pandang, terletak antara 119²4'17'38' Bujur Timur dan 5'8'6'19" Lintang Selatan yang berbatasan sebelah Utara dengan Kabupaten Maros, sebelah Timur Kabupaten Maros, sebelah selatan Kabupaten Gowa dan sebelah Barat adalah Selat Makassar. Kota Makassar memiliki topografi dengan kemiringan lahan 0$2^{\circ}$ (datar) dan kemiringan lahan 3-15 (bergelombang). Luas Wilayah Kota Makassar tercatat $175,77 \mathrm{~km}$ persegi. Kota Makassar memiliki kondisi iklim sedang hingga tropis memiliki suhu udara rata-rata berkisar antara $26,{ }^{\circ} \mathrm{C}$ sampai dengan $29^{\circ} \mathrm{C}$

Secara administrasi Kota Makassar dibagi menjadi 15 kecamatan dengan 153 kelurahan. Di antara 15 kecamatan tersebut, ada tujuh kecamatan yang berbatasan dengan pantai yaitu Kecamatan Tamalate, Kecamatan Mariso, Kecamatan Wajo, Kecamatan Ujung Tanah, Kecamatan Tallo, Kecamatan Tamalanrea, dan Kecamatan Biringkanaya. 
Batas-batas administrasi Kota Makassar adalah:

1. Batas utara : kabupaten Maros

2. Batas timur : kabupaten maros

3. Batas selatan : kabupaten gowa dan takalar

4. Batas barat : selat makassar

\section{Jenis dan Sumber Data}

1. Jenis Data

a. Data kuantitatif, yaitu data yang diperoleh dari beberapa rumah ayam potong dikota makassar

b. Data kualitatif, yaitu data yang diperoleh dalam bentuk informasi baik tulisan maupun lisan.

2. Sumber Data

a. Data sekunder, yaitu data yang diperoleh dari bahan dokumen dan bahan laporan tentang jenis penelitian yang berkaitan atau berhubungan erat dengan penelitian ini.

\section{Metode Pengumpulan Data}

1. Penelitian Kepustakaan (Library Search)

Penelitian kepustakaan merupakan sumber yang diperoleh dari buku-buku baik teks perkuliahan, jurnal, artikel, dokumen, internet dan sumber referensi lain yang juga diambil dari contoh penelitian sebelumnya. Penelitan kepustakaan adalah penelitian yang berguna untuk mengumpulkan data-data dengan jalur membaca literatur yang ada hubungannya dengan pemecahan masalah.

2. Penelitian Lapangan

Penelitian lapangan adalah suatu bentuk pengumpulan data yang dilakukan melalui penelitian langsung pada objek penelitian dengan menggunakan beberapa teknik pengumpulan data antara lain:

a. Observasi adalah penelitian dengan jalan mengamati secara langsung objek penelitian.

b. Wawancara adalah penelitian yang dilakukan dengan mengadakan tanya jawab langsung dengan narasumber yang bersangkutan dengan penelitian ini.

\section{HASIL DAN PEMBAHASAN}

Koordinasi merupakan penentua utama efektivitas suatu proses kegiatan dalam rantai pasok, karena koordinasi mencakup aliran infomasi, aliran material. Apabila korrdinasi dalam kegiatan rantai pasok tidak berjalan dengan baik, maka kinerja rantai pasok akan terganggu. Oleh karena itu. Koordinasi merupakan salah satu faktor pendukung yang sangat penting dan yang diperlukan untuk menunjang kinerja rantai pasokan khususnya kelancaran proses distribusi. Koordinasi aliran distribusi rantai pasok ayam pedaging dipeternakan. Seperti gambar berikut 

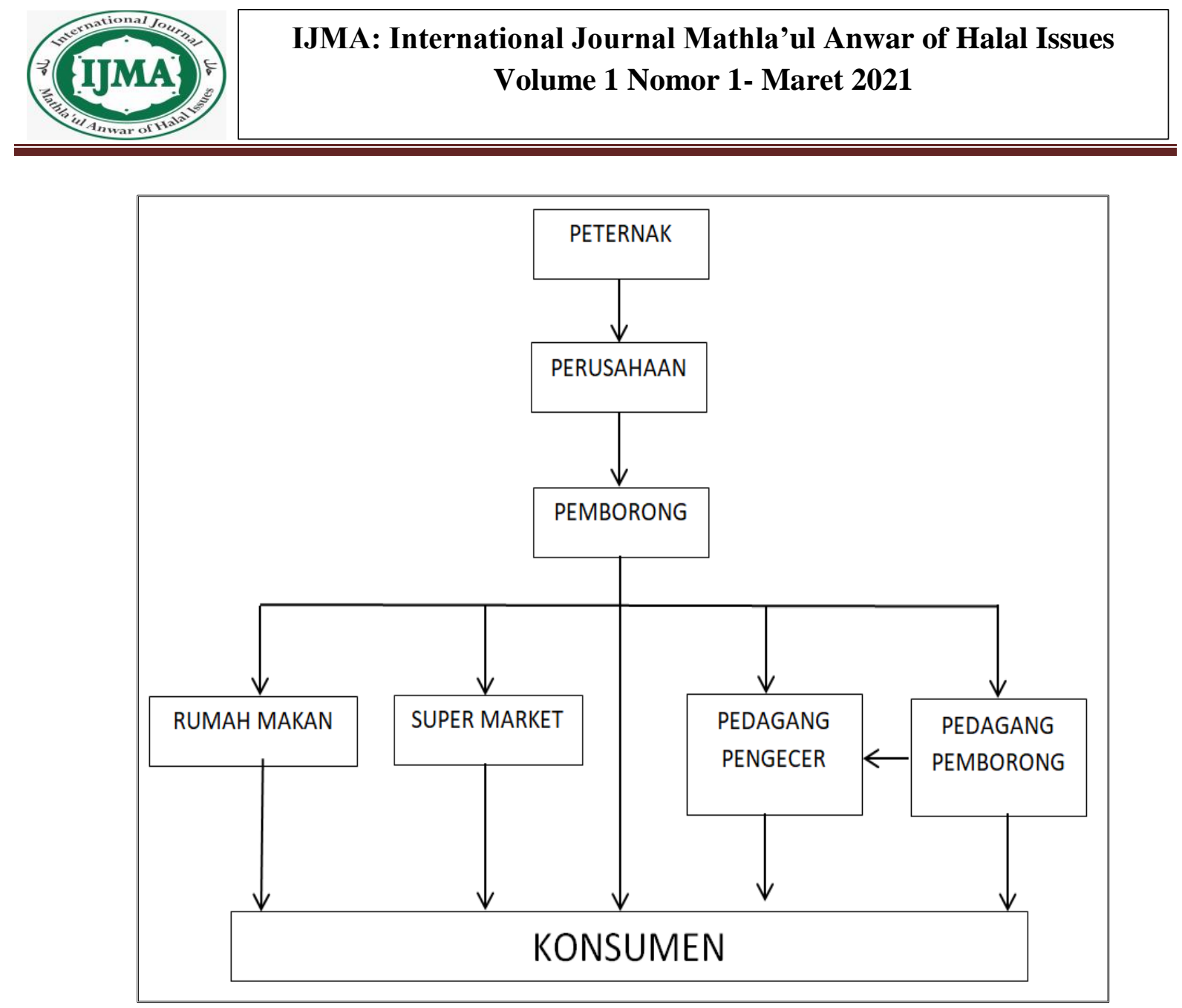

Gambar 2: Model aliran rantai pasok ayam potong dipeternakan

Menjelaskan model aliran rantai pasok ayam potong pada peternakan ayam dikota makassar yang terjadi saat ini, dari sisi hulu ke hilir maupun dari hilir ke hulu. Dimana berawal dari peternak yang membutuhkan 28-30 hari untuk proses peternakan sampai ayam siap untuk dipanen.kemudian ayam siap panen tersebut dijual kepada perusahaan dengan harga yang berbeda-beda. Selanjutnya perusahaan menjual ayam hasil produksi peternakan kepada pemborong yang sudah bekerja sama dan yang telah mengorder melalui perusahaan. Ditangan pemborong ayam potong hidup diproses menjadi daging ayam, kemudian disalurkan kepada pedagang pemborong, pedagang pengecer, rumah makan yang mengelolah daging ayam tersebut menjadi aneka jenis kuliner kemudiaan dijual kepada penikmat kuliner yang adalah konsumen akhir dari rumah makan. Dengan demikian rantai akhr dari proses rantai pasok ini berakhir pada konsumen.

Yang terjadi dalam rantai pasok ini yaitu setiap pihak atau anggota yang terlibat dalam aliran rantai pasok ini baik dari sisi hulu ke hilir maupun dari kehilir ke hulu saling koordinasikan dengan masing - masing mitra kerja untuk memenuhi setiap permintaan ayam potong. Selain itu setiap pihak yang terlibat saling berbagi informasi untuk menunjang kelancaran aliran rantai pasok. 


\section{Ketersediaan atau Kebutuhan Daging Sapi dalam 5 (Lima) Tahun di Kota Makassar}

Apabila dilakukan peramalan atau perkiraan ketersediaan ayam pedaging dalam mencapai target ketersediaan ayam pedaging 5 (lima) tahun, yaitu dari tahun 2018-2022 maka hasil yang di dapatkan dapat dilihat tabel 1

Tabel 1 Ketersediaan atau Kebutuhan ayam pedaging dalam 5 (Lima) Tahun di Kota Makassar

\begin{tabular}{cccrc}
\hline NO & TAHUN & $\begin{array}{c}\text { TARGET } \\
\text { KETERSEDIAAN } \\
\text { DAGING (KG) }\end{array}$ & $\begin{array}{c}\text { REALISASI } \\
\text { KETERSEDIAAN } \\
\text { DAGING (KG) }\end{array}$ & $\begin{array}{c}\text { PERSENTASE } \\
\text { REALISASI } \\
\text { DARI } \\
\text { TARGET (\%) }\end{array}$ \\
\hline 1 & 2018 & 500,000 & 378,718 & 38 \\
2 & 2019 & 500,000 & 365,084 & 38 \\
3 & 2020 & 500,000 & 378,592 & 37 \\
4 & 2021 & 500,000 & 365,341 & 35 \\
5 & 2022 & 500,000 & 378,493 & 36 \\
\hline
\end{tabular}

Sumber: Data Sekunder yang Telah Diolah, 2020

Berdasarkan Tabel 1, ramalan ketersediaan ayam daging potong dalam 5 (lima) tahun cenderung masih bersifat fluktuatif dengan prediksi ketersediaan ayam daging tertinggi terjadi pada tahun 2020 dengan total prediksi ketersediaan daging sapi sebanyak 378,592 kg ayam daging atau terealisasi sebanyak $37 \%$ dari target ketersediaan ayam daging, dan prediksi terendah terjadi pada tahun 2019 dengan total prediksi ketersediaan ayam daging sebanyak 365,084 $\mathrm{kg}$ daging atau terealisasi sebanyak $48 \%$ dari target ketersediaan ayam daging. Sehingga itu perlu adanya evaluasi dari pemerintah untuk ketersediaan ayam daging di kota Makassar terhadap peningkatan ketersediaan ayam daging agar dapat memenuhi target ketersediaan ayam daging yang telah direncanakan oleh pemerintah kota.

\section{Analisis Rantai Pasok Ayam Pedaging Kota Makassar}

Rantai pasok merupakan penentuan utama efektivitas suatu proses kegiatan dalam rantai pasok, karena koordinasi mencakup aliran infomasi, aliran material. Apabila kordinasi dalam kegiatan rantai pasok tidak berjalan dengan baik, maka kinerja rantai pasok akan terganggu. Oleh karena itu. Koordinasi merupakan salah satu faktor pendukung yang sangat penting dan yang diperlukan untuk menunjang kinerja rantai pasokan khsusnya kelancaran proses distribusi. aliran distribusi rantai pasok ayam pedaging dipeternakan. Seperti gambar berikut. 


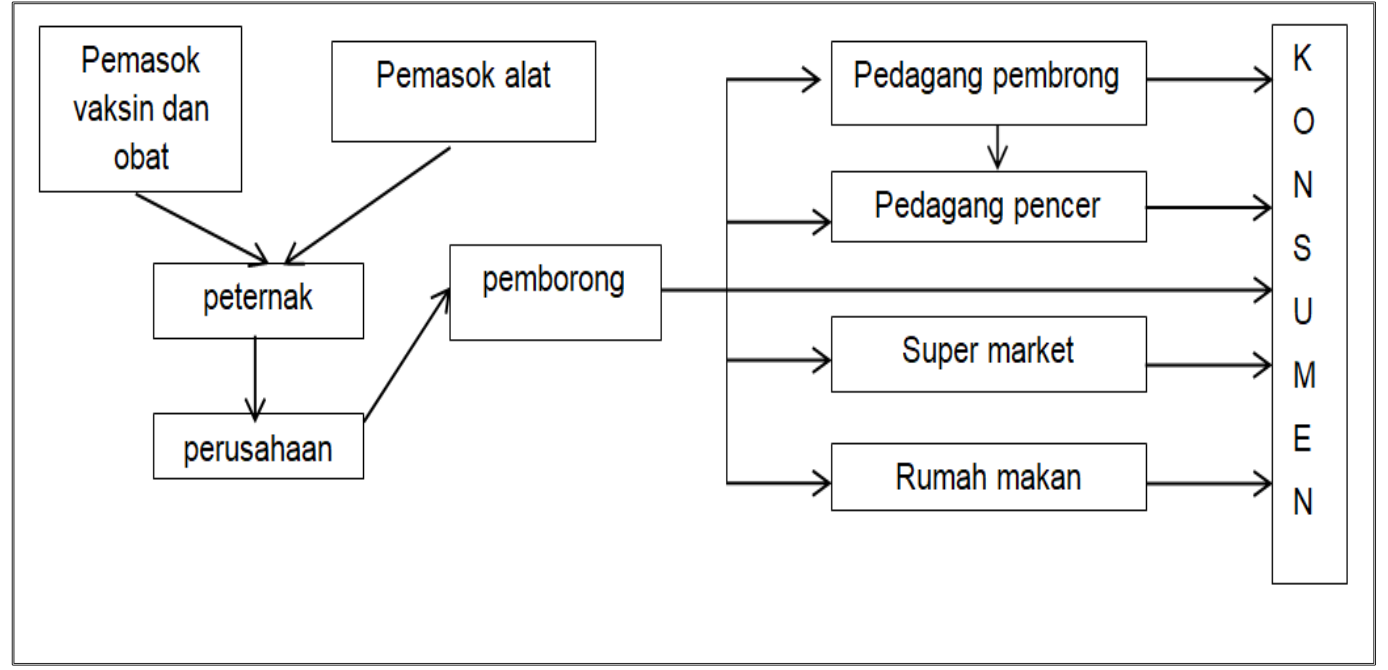

Gambar 3. Model Aliran Rantai Pasok Ayam Potong

Berdasarkan hasil penelitian diketahui bahwa, baik realisasi ketersediaan ayam daging dalam 5 (lima) tahun di kota Makassar mengalami fluktuasi jumlah ketersediaan ayam daging dari tahun ke tahun. Hal ini disebabkan oleh beberapa faktor, seperti luas lahan pertanian dan peternakan di kota Makassar yang semakin terdesak oleh pengembangan pembangunan kota, bahkan di prediksi tahun-tahun berikutnya pengembangan kota akan semakin berkembang, sehingga mengakibatkan populasi ayam potong di kota Makassar semakin berkurang bahkan habis sama sekali, sehingga untuk memenuhi ketersediaan ayam potong, diharapkan dari ayam - ayam dari daerah-daerah lain masuk di Rumah Potong Hewan (RPA). Selain itu, Walaupun demikian pada hakikatnya ketersediaan ayam potong di kota Makaassar tetap masih kurang sehingga perlu adanya evaluasi kebiajakan dari pemerintah kota maupun secara nasional untuk memenuhi ketersediaan ayam potong di tiap-tiap daerah, khususnya kepada daerah yang bukan lagi merupakan suatu daerah pengembangan.

\section{KESIMPULAN}

1. Aliran distribusi rantai pasok ayam pedaging di kota makassar yaitu peternakan menjual hasil produksi peternakan mereka kepada perusahaan, kemudian perusahaan menjual kepada pemborong mitra yang telah mengorder, selanjutnya pemborong memproses ayam pedaging hidup menjadi daging ayam lalu disalurkan kepada pedagang pemborong, pedagang pengecer, rumah makan, supermarket, serta dijual langsung kepada konsumen.

2. Penerpan kebijakan daging ayam potong untuk ketersediaan ayam pedaging di kota makassar dalam 5 tahun kedepan dinilai belum dapat mencapai target ketersediaan ayam pedaging yang telah dicanangkan oleh pemerintah kota makassar. 


\section{DAFTAR PUSTAKA}

Ambarsari Safitri, Setyanto Nasir Widha, Yuniarti Rahmi, 2014. Analisis Kinerja Proses Inti

Supply Chain Perusahaan Berdasarkan Pendekatan Lean Six Sigma Supply Chain Management (Studi Kasus di PT Semen Indonesia (Persero) Tbk). Malang . Universitas Brawijaya.

Daryanto, A. (2009) Daya Saing Industri Peternakan .Bogor: IPB Press.

Diana Desra Isma, Tawaf Rochadi, Paturochman Maman, 2016 Analisis Rantai pasok Sosis

Food Industri Dari Produsen Sampai Konsumen. Di Kota Bandung. Studi Kasus PT. Kemfood Cabang Kota Bandung. Fakultas Peternakan Universitas Padjadjaran.

Diwyanto, K., Priyanti, A., Setioko, A. R. Yusdja, Y., \& Saptati, R. A.(2005). Proses dan Arah pengembangan Agribisnis Unggas. Jakarta: Badan peneliti dan Pengembangan pertanian.

Ma'rifat, N.T., and Rahmawan, A, (2018). Pengembangan Kerangka Konseptual Model Rantai Pasok Halal Pada Komoditas Daging Ayam Di Kabupaten Ponorogo. Universitas Darussalam Grontalo.

Maulidya Nurul Shubuhi, 2014. Pengukuran Kinerja Supply Chain Managemen Dengan Pendekatan Supply Chain Operations Reference (SCOR) (Studi Kasus:UKM Batik Sekar Arum, Panjang, Sukarta) Universitas Muhammadiyah Sukara.

Ningsih, R., and Prabowo W. D, (2017). Tingkat Integrasi Pasar Ayam Broiler Di Sentra

Produksi Utama Studi Kasus Jawa Timur Dan Jawa Barat. BPPP Kementerian Perdagangan. Jakarta.

Nusran, Muhammad, 2019. Penyembelihan Sistem Halal Produk Ayam Potong. Penerbit:Nas Media Pustaka,Makassar.

Rasyaf, M. (1999) Manajmen Peternakan Ayam Broiler. Jakarta: Penebar Swadaya.

Pujawan, I Nyoman.,2005. Supply Chain Management. Surabaya: Guna Widya

Purwaningsih R, and Arif. M, Rahmawati, D, (2016). Analisis Rantai Pasok Dan Distribusi

Ayam Pedaging. Program Studi Teknik Industri. Universitas Diponegoro. Semarang.

Saptana, and Sartika. T, (2014). Manajemen Rantai Pasok Komoditas Telur Ayam Kampung. Pusat Sosial. Balai Penelitian Ternak. Ciawi-Bogor 


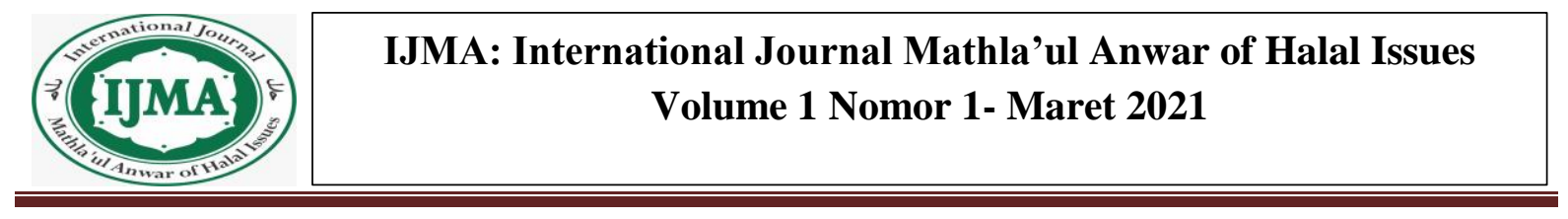

Saaty, T. L. 1993. The analytic hierarchy process for decision in complex world, Prentice Hall Co. Ltd, Pittsburgh

Vanany, Iwan. 2009. Performance Measurement Model dan Aplikasi: Surabaya Putra Media Nusantara. 